\title{
Explaining the High Cost of Higher Education to Black Americans: A Focus on Black American Women
}

\author{
Amadu Jacky Kaba \\ Department of Sociology, Anthropology and Social Work, South Orange, NJ, USA \\ Email:kabaamad@shu.edu
}

How to cite this paper: Kaba, A. J. (2017). Explaining the High Cost of Higher Education to Black Americans: A Focus on Black American Women. Sociology Mind, 7, 171-196.

https://doi.org/10.4236/sm.2017.74012

Received: July 26, 2017

Accepted: September 1, 2017

Published: September 4, 2017

Copyright $\odot 2017$ by author and Scientific Research Publishing Inc. This work is licensed under the Creative Commons Attribution International License (CC BY 4.0).

http://creativecommons.org/licenses/by/4.0/ c) (i) Open Access

\begin{abstract}
This article claims that Black Americans, especially Black women have made substantial progress in college enrollment and degree attainment in recent decades. From 2000 to 2015, Black American females were either second to Asian males or third to Asian males and Asian females in their proportion of those enrolled in college in the United States. In 2016, there were 2.446 million Black women and 1.841 million Black men aged 18 and over with at least a bachelor's degree. However, these achievements have come at a very high financial cost, compared to other groups. The factors cited for the high debt burden on Black American students, especially Black women include: the shift from grants to loans with interests to pay for college; lack of scholarships (research assistantship and traineeship) compared to students from other groups; the high cost of college education at for-profit institutions; and lack of funding from parents or family members. A number of recommendations to manage this problem, including increase in the number of "grant aid" and lowering the cost of undergraduate instruction, are presented in this article.
\end{abstract}

\section{Keywords}

Black Americans, Higher Education, High Cost, Gender, Grants, Scholarships, Black Women

\section{Introduction}

Among all of the groups and sub-groups in the United States, Black American females (women and girls) tend to work twice as hard or more to get any op- 
portunities or to be recognized. In discussing the gradual progress of Black women elected to state legislatures, Williams (2001: p. 314) notes that they are more educated than their male counterparts, and both White males and White females (also see Brown \& Banks, 2014: p. 174). Williams (2001: p. 314) then claims that, "In sum, the old adage black parents often tell their children, "You've got to work twice as hard to get half as far", seems to partially explain the puzzle..." of the successes that Black women are having being elected to public office. Educational attainment is a very important variable when it comes to being elected to political office in the United States. For example, during the $108^{\text {th }}$ U.S. Congress (January 3, 2003 to January 3, 2005), over $92 \%$ of all 535 members of Congress had at least a bachelor's degree (Kaba \& Ward, 2009: p. 36). The data in this article will show that Black women have higher college enrollment and more overall college degrees than their male counterparts. Black women are more in number and are older on average than their male counterparts. These are the variables that contribute to being elected to political office. However, Black women accounted for $40.9 \%$ of Black members of the U.S. House of Representatives in 2015 (Dittmar, 2015: p. 5), and there is only one Black woman in the United States Senate, but two Black men are serving in that body (Kaba, 2017).

In 2011, Blacks accounted for $6 \%$ of all college presidents in the United States, but Black women accounted for $34 \%$ of those Black presidents. As of January 2016, of the five Black CEOs of Fortune 500 companies, only 1 was a Black woman (McGirt, 2016: p. 52, January 22). Black women in U.S. higher education are also less likely to get tenure, promotion or endowed or distinguished professorships (Kaba, 2016). There were 9,040,816 Black females aged 16 and over and 7,624,429 Black males aged 16 and older in the civilian labor force in 2014, with $33.4 \%$ of Black females in management, business, science, and arts occupations (the highest job category in the nation); and $23 \%$ of their male counterparts in that same employment category. However, in 2010, the median usual weekly earnings of those who work full-time in that top employment category, Asian men earned \$1408; White men earned \$1273; Asian women earned \$1143; Hispanic men earned \$1002; Black men earned \$957; White women earned \$932; and Black women earned $\$ 812$. In addition, $46 \%, 42 \%$, and $34 \%$ of Asian women, White women, and Black women respectively were employed in management, professional, and related jobs in 2010 (United States Bureau of Labor Statistics, 2016).

This current work illustrates a continuation of this trend, whereby although Black women are among the top groups enrolled in college and have also substantially increased their overall numbers of various types and levels of college or university degrees, they are paying a very high financial cost for their higher education, compared with members of other racial and cultural groups.

This article examines the high cost of higher education to Black Americans, focusing on Black women. The article begins by presenting data on the trends in college enrollment and degree attainment of Black Americans, focusing on Black 
women. Next, the paper presents evidence showing that Blacks, especially Black females pay far too much for their education. Next, the factors responsible for the high cost of college education to Black Americans, especially Black females are presented. Finally, some recommendations for reducing this high debt burden on Black American students, especially Black women are presented.

\section{College Enrollment and Degree Attainment Trends of Black Americans}

When higher education enrollment and degree attainment data of the United States are carefully examined, one finds that Black Americans, especially Black women have made substantial progress over the past century. According to Thomas \& Jackson (2007: p. 367), in 1862, a Black American woman named Mary Jane Patterson became the first of her group to earn a Bachelor of Arts degree from an established institution in the United States (Oberlin College in Ohio). Since that period, Black American women have made gradual progress in higher education attainment until the current period, where they earn more college degrees than their male counterparts in almost all academic levels and disciplines. Musser (1997: p. 78) points out that prior to the start of the 1900s, there were 2079 Black Americans recorded to have earned a college degree. In 1917, there were only 2132 Black Americans enrolled in college, and that figure increased to 13,580 a decade later. In 1930, an estimated 19,000 students were enrolled in historically Black higher education institutions. In 1970, an estimated 378,000 Black Americans were enrolled in higher education institutions (Franklin \& Moss, 1994: p. 9). By the mid-1970s, more Black females had enrolled in colleges and universities in almost all levels than Black males. In 1976, of the 1,033,000 Black students enrolled in higher education institutions, 563,100 (54.5\%) were females and 469,900 (45.9\%) were males (Kaba, 2005: p. 2). According to Iloh \& Toldson (2013: p. 205), in 1982, 40\% of Black American students and $53 \%$ of White students enrolled into college after graduation from high school, and that by 2011 the figures were 65\% for Black Americans and 69\% for White Americans.

The United States Census Bureau annually publishes college (undergraduate and graduate) enrollment data for individuals in the United States "aged three and over by sex, age, race, and Hispanic origin". In each of the 16 years from 2000 to 2015, Black females have ranked second after Asian males, or third after Asian males and Asian females. For example, in 2015, the college enrollment rates were 9.5\% for Asian females, 9.3\% for Asian males, and $8 \%$ for "Black Alone" females (United States Census Bureau, 2016). It is useful to note that part of the reason for Asians ranking so high in college enrollment is due to the massive number of international students from Asia enrolled in U.S. colleges and universities. For example, of the 974,926 international students enrolled in U.S. colleges and universities during the 2014-2015 academic year, 627,306 (64.3\%) are from Asia (Fact Sheets by Region: 2015, 2016). 
In this section, the focus is on college enrollment data for the year 2012 because it shows the most recent year that Black females ranked second to Asian males. According to Table 1, of the 21.842 million Black females aged 3 and over as of October 2012, 2.043 million (9.4\%) were enrolled in college. The average for females in general was 7.4\% (11.33 million out of 152.33 million); $6.8 \%$ (6.6 million out of 96.4 million) of non-Hispanic White females; 7.6\% (1.89 million out of 24.75 million) of Hispanic females; and 9.2\% (747,000 out of 8.116 million) of Asian females. Among males, Asians had the highest rate, and also among all groups: $9.5 \%$ (700,000 out of 7.356 million); $5.9 \%$ (8.6 million out of 144.9 million) of males in general; 5.5\% (5.074 million out of 92.3 million) of non-Hispanic Whites; $6.8 \%$ (1.3 million out of 18.973 million) of Blacks; and 6\% (1.5 million out of 25.1 million) of Hispanics.

\section{Numbers and Percentages of Americans with College Degrees, 2015}

The United States Census Bureau also annually publishes educational attainment data for individuals in the United States from various racial/ethnic groups. Black women have made steady progress in degree attainment in recent decades. Here we focus on the following for those aged 18 years and over, and 25 years and over: bachelor's, master's, professional, and doctoral degrees for the year 2016. According to Table 2(a), in 2016, among women, Asians aged 18 and over had the highest proportion (30.8\%) of bachelor's degrees (2.366 million out of 7.674 million); 22.4\% for non-Hispanic Whites (18.122 million out of 80.765 million); $14 \%$ for Blacks (2.446 million out of 17.491 million); and $10.6 \%$ for Hispanics (2.044 million out of 19.362 million).

For men aged 18 and over, Asians had the highest proportion (30\%) of bachelor's degrees (2.034 million out of 6.781 million); $21.7 \%$ for non-Hispanic Whites (16.690 million out of 76.826 million); $12.6 \%$ for Blacks (1.841 million out of 14.608 million); and $9.4 \%$ for Hispanics (1.801 million out of 19.187

Table 1. College enrollment status of the population 3 years old and over, by sex, age, race, and hispanic origin, October 2012.

\begin{tabular}{lcccccc}
\hline \multicolumn{1}{c}{ Category } & Male Total & $\begin{array}{c}\text { Number } \\
\text { Enrolled }\end{array}$ & $\%$ & $\begin{array}{c}\text { Female } \\
\text { Total }\end{array}$ & $\begin{array}{c}\text { Number } \\
\text { Enrolled }\end{array}$ & $\%$ \\
\hline All Races & $144,902,000$ & $8,602,000$ & 5.9 & $152,326,000$ & $11,327,000$ & 7.4 \\
Asian Alone & $7,356,000$ & 700,000 & 9.5 & $8,116,000$ & 747,000 & 9.2 \\
$\begin{array}{l}\text { Black Alone or in } \\
\text { Combination }\end{array}$ & $18,973,000$ & $1,292,000$ & 6.8 & $21,842,00$ & $2,043,000$ & 9.4 \\
$\begin{array}{l}\text { Hispanic } \\
\text { Non-Hispanic Whites }\end{array}$ & $25,131,000$ & $1,510,000$ & 6.0 & $24,748,000$ & $1,890,000$ & 7.6 \\
\hline
\end{tabular}

Source: Compiled and computed by author from "School Enrollment: CPS October 2012 - Detailed Tables", United States Census Bureau (2013). Retrieved on October 9, 2016 from:

http://www.census.gov/hhes/school/data/cps/2012/tables.html. 
million). For master's degrees, Asian men, Asian women and non-Hispanic White women aged 18 and over are the only groups with double figures, $16.4 \%$ (1.115 million), $14.2 \%$ (1.091 million) and $10.2 \%$ (8.216 million) respectively; $8.5 \%$ for non-Hispanic White men (6.498 million); 6.8\% for Black women (1.180 million); $4.8 \%$ for Black men (712,000); 3.9\% for Hispanic women (755,000); and $2.8 \%$ for Hispanic men $(530,000)$.

For professional degrees such as Juris Doctor and Doctor of Medicine degrees, Asian men and Asian women aged 18 and over had the highest proportions, 2.5\% $(166,000)$ and $2 \%(150,000)$ respectively; $1.9 \%$ (1.492 million) for non-Hispanic White men; $1.2 \%$ for non-Hispanic White women $(951,000) ; 0.8 \%$ for Black women $(137,000) ; 0.5 \%$ for Black men $(73,000)$; $0.6 \%$ for Hispanic men $(112,000)$; and $0.5 \%$ for Hispanic women (100,000).

For doctoral degrees such as a Ph.D or Ed.D, Asian men and Asian women aged 18 and over again had the highest proportions, 5.3\% $(359,000)$ and $3.3 \%$ $(252,000)$ respectively; $2.3 \%$ (1.730 million) for non-Hispanic White men; $1.5 \%$ for non-Hispanic White women (1.180 million); 0.8\% for Black men (123,000); $0.8 \%$ for Black women (136,000); $0.6 \%$ for Hispanic women $(115,000)$; and $0.6 \%$ for Hispanic men $(116,000)$ (Table 2(a)).

According to Table 2(b), in 2016, Asian women and Asian men aged 25 and over had the highest proportions of Bachelor's degrees in the United States, 32.1\% (2.186 million out of 6.813 million) and 31.5\% (1.869 million out of 5.933 million) respectively; $22.2 \%$ (15.869 million out of 68.536 million) for non-Hispanic White men; 22.2\% for non-Hispanic White women (16.922 million out of 72.878 million); $15.4 \%$ for Black women (2.301 million out of 14.957 million); $14.4 \%$ for Black men (1.739 million out of 12.121 million); $11.6 \%$ for Hispanic women (1.866 million out of 16.122 million); and $10.7 \%$ for Hispanic men (1.7 million out of 15.896 million) (Table 2(b)).

For comparative purposes, in $1970,4.2 \%$ of Black men and $4.6 \%$ of Black women aged 25 and over had at least a bachelor's degree; $14.4 \%$ of White men; 8.4\% of White women; $23.5 \%$ of Asian and Pacific Islander men; $17.3 \%$ of Asian and Pacific Islander women; and $7.8 \%$ of Hispanic men and $4.3 \%$ of Hispanic women (Table 230, Educational Attainment, by Race, Hispanic Origin, and Sex, $1970-2010,2012)$. Black women had an increase of 10.8 percentage points from 1970 to $2015 ; 10.2$ percentage points for Black men.

Table 2(b) shows that for master's degrees, in 2016, Asian men and Asian women aged 25 and over led all groups: 18.5\% (1.097 million) and 15.6\% (1.060 million) respectively; $11.2 \%$ (8.140 million) for non-Hispanic White women; $9.4 \%$ (6.442 million) for non-Hispanic White men; 7.7\% (1.154 million) for Black women; $5.8 \%$ for Black men $(708,000) ; 4.6 \%(738,000)$ for Hispanic women; and $3.3 \%(523,000)$ for Hispanic men.

For professional degrees, Asian men, Asian women and non-Hispanic White men aged 25 and over had the highest proportions, $2.8 \%(166,000), 2.2 \%$ $(150,000)$ and $2.2 \%$ (1.477 million) respectively; $1.3 \%(938,000)$ for non-Hispanic 
Table 2. (a) College degree attainment of the population 18 years and over, by sex, age, race, and hispanic origin: 2016; (b) College degree attainment of the population 25 years and over, by sex, age, race, and hispanic origin: 2016.

(a)

\begin{tabular}{|c|c|c|c|c|c|c|c|c|c|}
\hline \multicolumn{10}{|c|}{ Male } \\
\hline Race & Total & Bachelor's & $\%$ & Master's & $\%$ & Professional & $\%$ & Doctoral & $\%$ \\
\hline All Races & $118,467,000$ & $22,485,000$ & 19 & $8,916,000$ & 7.5 & $1,858,, 000$ & 1.6 & $2,336,000$ & 2 \\
\hline Asian & $6,781,000$ & $2,034,000$ & 30 & $1,115,000$ & 16.4 & 166,000 & 2.5 & 359,000 & 5.3 \\
\hline Black Alone or in Combination & $14,608,000$ & $1,841,000$ & 12.6 & 712,000 & 4.8 & 73,000 & 0.5 & 123,000 & 0.8 \\
\hline Hispanic (of any Race) & $19,187,000$ & $1,801,000$ & 9.4 & 530,000 & 2.8 & 112,000 & 0.6 & 116,000 & 0.6 \\
\hline Non-Hispanic White & $76,826,000$ & $16,690,000$ & 21.7 & $6,498,000$ & 8.5 & $1,492,000$ & 1.9 & $1,730,000$ & 2.3 \\
\hline \multicolumn{10}{|c|}{ Female } \\
\hline Race & Total & Bachelor's & $\%$ & Master's & $\%$ & Professional & $\%$ & Doctoral & $\%$ \\
\hline All Races & $126,339,000$ & $25,234,000$ & 20 & $11,271,000$ & 9 & $1,352,000$ & 1.1 & $1,669,000$ & 1.4 \\
\hline Asian & $7,674,000$ & $2,366,000$ & 30.8 & $1,091,000$ & 14.2 & 150,000 & 2 & 252,000 & 3.3 \\
\hline Black Alone or in Combination & $17,491,000$ & $2,446,000$ & 14 & $1,180,000$ & 6.8 & 137,000 & 0.8 & 136,000 & 0.8 \\
\hline Hispanic (of any Race) & $19,362,000$ & $2,044,000$ & 10.6 & 755,000 & 3.9 & 100,000 & 0.5 & 115,000 & 0.6 \\
\hline Non-Hispanic White & $80,765,000$ & $18,122,000$ & 22.4 & $8,216,000$ & 10.2 & 951,000 & 1.2 & $1,180,000$ & 1.5 \\
\hline
\end{tabular}

Source: Compiled and computed by author from "Educational Attainment in the United States: 2016 - Detailed Tables", U.S. Census Bureau (2017). Retrieved on August 2, 2017 from: https://www.census.gov/data/tables/2016/demo/education-attainment/cps-detailed-tables.html.

(b)

\begin{tabular}{|c|c|c|c|c|c|c|c|c|c|}
\hline \multicolumn{10}{|c|}{ Male } \\
\hline Race & Total & Bachelor's & $\%$ & Master's & $\%$ & Professional & $\%$ & Doctoral & $\%$ \\
\hline All Races & $103,372,000$ & $21,281,000$ & 20.6 & $8,829,000$ & 8.5 & $1,841,000$ & 1.8 & $2,332,000$ & 2.3 \\
\hline Asian & $5,933,000$ & $1,869,000$ & 31.5 & $1,097,000$ & 18.5 & 166,000 & 2.8 & 359,000 & 6.1 \\
\hline Black Alone or in Combination & $12,121,000$ & $1,739,000$ & 14.4 & 708,000 & 5.8 & 73,000 & 0.6 & 123,000 & 1 \\
\hline Hispanic (of any Race) & $15,896,000$ & $1,700,000$ & 10.7 & 523,000 & 3.3 & 110,000 & 0.7 & 116,000 & 0.7 \\
\hline Non-Hispanic White & $68,536,000$ & $15,869,000$ & 23.2 & $6,442,000$ & 9.4 & $1,477,000$ & 2.2 & $1,725,000$ & 2.5 \\
\hline \multicolumn{10}{|c|}{ Female } \\
\hline Race & Total & Bachelor's & $\%$ & Master's & $\%$ & Professional & $\%$ & Doctoral & $\%$ \\
\hline All Races & $111,643,000$ & $23,497,000$ & 21.1 & $11,129,000$ & 10 & $1,337,000$ & 1.2 & $1,654,000$ & 1.5 \\
\hline Asian & $6,813,000$ & $2,186,000$ & 32.1 & $1,060,000$ & 15.6 & 150,000 & 2.2 & 242,000 & 3.6 \\
\hline Black Alone or in Combination & $14,957,000$ & $2,301,000$ & 15.4 & $1,154,000$ & 7.7 & 137,000 & 0.9 & 136,000 & 0.9 \\
\hline Hispanic (of any Race) & $16,122,000$ & $1,866,000$ & 11.6 & 738,000 & 4.6 & 98,000 & 0.6 & 104,000 & 0.7 \\
\hline Non-Hispanic White & $72,878,000$ & $16,922,000$ & 23.2 & $8,140,000$ & 11.2 & 938,000 & 1.3 & $1,177,000$ & 1.6 \\
\hline
\end{tabular}

Source: Compiled and computed by author from "Educational Attainment in the United States: 2016 - Detailed Tables", U.S. Census Bureau (2017). Retrieved on August 2, 2017 from: https://www.census.gov/data/tables/2016/demo/education-attainment/cps-detailed-tables.html.

White women; $0.9 \%$ for Black women $(137,000)$; $0.7 \%(110,000)$ for Black men; $0.6 \%(73,000)$ for Hispanic men; and $0.6 \%(98,000)$ for Hispanic women. 
For doctoral degrees, Asian men and Asian women aged 25 and over had the highest proportions, $6.1 \%(359,000)$ and $3.6 \%(242,000)$ respectively; $2.5 \%(1.725$ million) for non-Hispanic White men; $1.6 \%$ (1.177 million) for non-Hispanic White women; $1 \%(123,000)$ for Black men; $0.9 \%(136,000)$ for Black women; 0.7\% $(104,000)$ for Hispanic women; and $0.7 \%(116,000)$ for Hispanic men (Table 2(b)).

Let us now turn to the doctoral degree attainment of Black American women, relative to their male counterparts and other groups. It is important to provide this data because it contributes to explaining why Black American women pay such a high financial cost for their college education.

\section{Doctoral Degree Recipients in the United States, by Race, Gender and Foreign-Born Status, 2015}

The data for doctoral degree attainment in this section is from the National Science Foundation (NSF) for the year 2015. Colleges and universities in the United States confer tens of thousands of doctoral degrees annually to students from all racial, ethnic and cultural backgrounds. They also confer doctoral degrees to international students from dozens of nations from all over the world. Data for 2015 doctoral degree recipients in the United States by sex, gender, race, ethnicity and citizenship status were broken down into two tables (males and females) by the NSF. I compiled the data for each group and computed them in one table (Table 3 below). According to Table 3, of 54,999 doctoral degrees awarded by higher education institutions in the United States in 2015, males accounted for 29,596 (53.8\%), and females accounted for 25,403 (46.2\%).Male United States citizens and permanent residents earned $31.4 \%$ of the 54,999 doctoral degrees. Male temporary visa holders earned $18.9 \%$ of all doctoral degrees. Female United States citizens and permanent residents earned 32.5\% of the total. Female temporary visa holders earned $10.4 \%$ of all doctoral degrees.

These statistics above suggest two interesting observations about American citizenship and educational attainment. First, we shall learn below later that more female U.S. citizens and permanent residents earn doctoral degrees in 2015 than their male counterparts because citizens and permanent residents qualify to take out loans from the federal government to pay for their college education and pay off those loans after they graduate. Therefore, females have higher debt among this cohort than their male counterparts. Second, most of these colleges and universities in the United States conferring these doctoral degrees have become not just national, but international institutions competing for the most talented students from all over the world. In addition, these talented international students, who are responsible for the overall gender gap favoring males, are recruited and offered grants or scholarships, or they pay the full tuition and fees and contribute to the local economies where the institutions they are enrolled in are located. So here one can see that American citizenship can lead to qualification for federal government loans for college, but on the other hand, institutions 
have a form of sovereignty to seek talented students from across the globe. In many instances, when these international students earned their terminal degrees, they are recruited again by businesses, the government, colleges and universities, etc. and encouraged to remain and work and become American citizens. American citizenship or green card can lead to educational attainment, and educational attainment can lead to American citizenship.

Among racial and ethnic groups, White males earned $27.5 \%$ and White females earned $24.6 \%$ of the 54,999 doctoral degrees awarded in the United States in 2015. Asian males earned $15 \%$ of all doctoral degrees and their female counterparts earned $10.2 \%$ of total. Black females earned $3 \%$ of all doctoral degrees and their male counterparts earned $2.4 \%$ of the total. Hispanic females earned 3\% of all doctoral degrees, and their male counterparts earned 3.2 percent. Female American Indians and Alaska Natives earned $0.14 \%$ of all doctorates and their male counterparts earned $0.1 \%$ of the total (Table 3 ).

Within their racial category, in 2015 , White males earned $51.1 \%$ of all 28,659 doctoral degrees and their female counterparts earned 47.2\%; Asian males earned $59.5 \%$ of all 13,846 doctoral degrees awarded to their group, and their female counterparts earned 40.5\%; Black females earned $59.7 \%$ of all 2781 doctoral degrees earned by Blacks and their male counterpart earned 40.3\%; Hispanic males earned $51.4 \%$ of all 3423 doctoral degrees earned by their group and their female counterparts earned the remaining 48.6\%; and female American Indians and Alaska Natives earned $54.3 \%$ of all 140 doctorates awarded to their group and their male counterparts accounted for 45.7 percent (Table 3).

Among males, of the 29,596 doctoral degrees earned, 50.3\% were awarded to Whites; $27.9 \%$ earned by Asians; $6 \%$ earned by Hispanics; 3.8\% earned by Blacks; and $0.2 \%$ earned by American Indians and Alaska Natives. Among females, of the 25,403 doctoral degrees earned, $53.3 \%$ were awarded to Whites; $22.1 \%$ earned by Asians; $6.6 \%$ earned by Hispanics; $6.5 \%$ earned by Blacks; and $0.3 \%$ earned by American Indians and Alaska Natives (Table 3).

Among U.S. citizens and permanent residents, of the 25,407 doctoral degrees awarded to Whites, males earned $51.2 \%$ and females earned $48.9 \%$; for Asians, females earned $55.8 \%$ of the 3072 doctoral degrees, and their male counterparts earned $44.2 \%$; for Blacks, females earned $64.4 \%$ of the 2281 doctoral degrees and their male counterparts earned 35.6\%; Hispanic females earned $54.3 \%$ of the 21,451 doctoral degrees and their male counterparts earned 45.7\%; and for American Indians and Alaska Natives, females earned 55.4\% of the 130 doctoral degrees and their male counterparts earned $44.6 \%$ (Table 3 ).

It is also useful to point out that Black women are among individuals who earn their doctoral degrees at a relatively young age. As Kaba (2012: p. 133) points out, of the 117,000 doctoral degrees held by individuals in the United States 25 - 29 years old in 2009, women comprised 65,000 (55.6\%), with Black women and Asian women comprising $11.1 \%(13,000)$ and $10.3 \%(12,000)$ respectively. Also, in 2008, of the 14,000 doctoral degrees held by individuals 
Table 3. Doctoral degree recipients in the united states, by sex, race, ethnicity, and citizenship: 2015.

\begin{tabular}{|c|c|c|c|c|c|c|c|c|c|}
\hline & & & $\%$ of & $\%$ within & $\%$ of Overall & & $\%$ of all & $\%$ within & $\%$ of Overall \\
\hline & Total & Male & all Males & Own Group & Total & Female & Females & Own Group & Total \\
\hline All doctorate recipients & 54,999 & 29,596 & & 53.8 & 53.8 & 25,403 & & 46.2 & 46.2 \\
\hline $\begin{array}{l}\text { U.S. citizen \& Permanent } \\
\text { resident }\end{array}$ & 35,117 & 17,245 & 58.3 & 49.1 & 31.4 & 17,872 & 70.4 & 50.9 & 32.5 \\
\hline Temporary visa holder & 16,155 & 10,413 & 35.2 & 64.5 & 18.9 & 5742 & 22.6 & 35.5 & 10.4 \\
\hline Unknown citizen & 3727 & 1938 & 6.5 & 52 & 3.5 & 1789 & 7 & 48 & 3.3 \\
\hline $\begin{array}{l}\text { American Indian or } \\
\text { Alaskan Native }\end{array}$ & 140 & 64 & 0.2 & 45.7 & 0.1 & 76 & 0.3 & 54.3 & 0.14 \\
\hline $\begin{array}{l}\text { U.S. citizen \& Permanent } \\
\text { resident }\end{array}$ & 130 & 58 & 0.2 & 44.6 & 0.1 & 72 & 0.3 & 55.4 & 0.14 \\
\hline Temporary visa holder & & $\mathrm{D}$ & & & & $\mathrm{D}$ & & & \\
\hline Unknown citizen & & $\mathrm{D}$ & & & & $\mathrm{D}$ & & & \\
\hline Asian & 13,846 & 8244 & 27.9 & 59.5 & 15 & 5602 & 22.1 & 40.5 & 10.2 \\
\hline $\begin{array}{l}\text { U.S. citizen \& Permanent } \\
\text { resident }\end{array}$ & 3072 & 1359 & 4.6 & 44.2 & 2.5 & 1713 & 6.7 & 55.8 & 3.1 \\
\hline Temporary visa holder & 10,754 & 6876 & 23.2 & 64 & 12.5 & 3878 & 15.4 & 35.8 & 7.1 \\
\hline Unknown citizen & 20 & 9 & 0.03 & 45 & 0.02 & 11 & 0.04 & 55 & 0.02 \\
\hline Black & 2781 & 1,121 & 3.8 & 40.3 & 2.4 & 1660 & 6.5 & 59.7 & 3 \\
\hline $\begin{array}{l}\text { U.S. citizen \& Permanent } \\
\text { resident }\end{array}$ & 2281 & 813 & 2.7 & 35.6 & 1.5 & 1468 & 5.8 & 64.4 & 2.7 \\
\hline Temporary visa holder & 495 & 308 & 1 & 62.2 & 0.6 & 187 & 0.74 & 37.8 & 0.34 \\
\hline Unknown citizen & 5 & 0 & 0 & 0 & 0 & 5 & 0.02 & 100 & 0.009 \\
\hline Hispanic & 3423 & 1758 & 6 & 51.4 & 3.2 & 1665 & 6.6 & 48.6 & 3 \\
\hline $\begin{array}{l}\text { U.S. citizen \& Permanent } \\
\text { resident }\end{array}$ & 2451 & 1119 & 3.8 & 45.7 & 2 & 1332 & 5.2 & 54.3 & 2.4 \\
\hline Temporary visa holder & 963 & 634 & 2 & 65.8 & 1.2 & 329 & 1.3 & 34.2 & 0.6 \\
\hline Unknown citizen & 9 & 5 & 0.02 & 55.6 & 0.01 & 4 & 0.02 & 44.4 & 0.007 \\
\hline White & 28,659 & 15,123 & 50.3 & 51.1 & 27.5 & 13,536 & 53.3 & 47.2 & 24.6 \\
\hline $\begin{array}{l}\text { U.S. citizen \& Permanent } \\
\text { resident }\end{array}$ & 25,407 & 12,996 & 43.9 & 51.2 & 23.6 & 12,411 & 48.8 & 48.9 & 22.6 \\
\hline Temporary visa holder & 3185 & 2104 & 7 & 66 & 3.8 & 1081 & 4.3 & 34.6 & 2 \\
\hline Unknown citizen & 67 & 23 & 0.08 & 34.3 & 0.04 & 44 & 0.2 & 65.7 & 0.08 \\
\hline More than one race & 973 & 436 & 1.5 & 44.8 & 0.8 & 537 & 2 & 55.2 & 1 \\
\hline $\begin{array}{l}\text { U.S. citizen \& Permanent } \\
\text { resident }\end{array}$ & 905 & 394 & 1.3 & 43.5 & 0.7 & 511 & 2 & 56.5 & 1 \\
\hline Temporary visa holder & 67 & 42 & 0.14 & 62.7 & 0.08 & 25 & 0.1 & 37.3 & 0.05 \\
\hline Unknown citizen & 1 & 0 & 0 & 0 & 0 & 1 & 0.004 & 100 & 0.002 \\
\hline
\end{tabular}

${ }^{*} \mathrm{D}=$ suppressed to avoid disclosure of confidential information; Source: Compiled and computed by author from "Table 20. Male doctorate recipients, by ethnicity, race, and citizenship status: 2005-15," (2016). National Science Foundation. Retrieved on January 2, 2016 from:

https://www.nsf.gov/statistics/2017/nsf17306/data/tab20.pdf; and "Table 21. Female doctorate recipients, by ethnicity, race, and citizenship status: 2004-14," (2016). National Science Foundation. Retrieved on January 2, 2016 from: https:/www.nsf.gov/statistics/2017/nsf17306/data/tab21.pdf. 
18 - 24 years old in the United States, women comprised 11,000 (78.6\%), and Black women and Asian women each comprised 4000 (28.6\%) (also see Kaba, 2016).

The college enrollment and degree attainment data presented above show that Black American women in particular, and Black Americans in general have made substantial progress in educational attainment in the United States in the past century alone. However, it appears that this achievement in higher education by Black American women is happening at a great financial cost to them. Many studies have noted this fact about the debt burden of college students in general, but the debt levels have continued to increase substantially more for Black Americans, especially Black American women, up to the most recent period.

Grinstein-Weiss et al. (2016: p. 166) point out that "Education loan debt has reached \$1.2 trillion in the United States, surpassing credit card as the largest form of consumer debt”. Avery \& Turner (2012: p. 165) claim that by 2010, the total debt of college students increased to more than $\$ 800$ billion. This amount was more than all outstanding credit card debt for the first time in the history of the United States. In the 2009-2010 academic year, new federal government loans to students was $\$ 97$ billion, with $\$ 66.8$ billion going to undergraduate students and $\$ 31$ billion going to graduate students. Since the early 1990s, taking out loans to pay for college education has quadrupled. According to Trent et al. (2006: pp. 1740-1741): “...college graduates’ average debt, from 4-year public institutions, doubled from 1991 to 2000, making it US\$19,300 in 2000.” According to the College Board, “The percentage of bachelor's degree recipients graduating with $\$ 40,000$ or more of student loan debt (in 2012 dollars) increased from $2 \%$ in 2003-04 to 8\% in 2007-08 and to 18\% in 2011-12". The College Board adds that, "Almost half of the 2011-12 bachelor's degree recipients from for-profit institutions had borrowed $\$ 40,000$ or more, but only $12 \%$ of those from public institutions had this much debt". These figures include both federal and non-federal borrowing (Cumulative Debt of Bachelor's Degree Recipients by Sector over Time, 2015).

In a study examining the borrowing patterns of STEM (Science, Technology, Engineering, and Mathematics) students (U.S. citizens) in college based on their racial/ethnic background in 2000-2001 and 2001-2002, Malcolm \& Dowd (2012: p. 86) find that Asian students with bachelor's degrees in STEM borrowed the least among students from various racial groups: over $40 \%$ of them did not borrow anything for their education, while only $13.3 \%$ of them borrowed heavily, which is the smallest percentage. For White students with bachelor's degrees in STEM, 35.5\% had no debt, $42.5 \%$ had a typical debt level, and $22.1 \%$ had heavy debt. For Hispanic students with bachelor's degrees in STEM, 51.3\% had typical debt levels, 20.8\% had heavy debt, and 27.9\% had no debt. For Black American students with Bachelor's degrees in STEM, 31.9\% of them had heavy debt, and $47.9 \%$ had typical debt levels. In terms of absolute debt, $26.1 \%$ of Black American students had debt levels of over $\$ 25,000 ; 17.9 \%$ of White students; $16.3 \%$ of Hispanic students; and less than $12 \%$ of Asian students (also see Grinstein-Weiss 
et al., 2016: pp. 169-170).

According to Table 4, among 2015 doctoral degree recipients in the United States, the mean cumulative (undergraduate and graduate) debt was $\$ 62,848$ for Black Americans; $\$ 50,210$ for American Indians and Alaska Natives; $\$ 36,870$ for Hispanics; $\$ 32,430$ for those who are more than one race; $\$ 28,086$ for Whites; and $\$ 15,186$ for Asians. The percentage of doctoral degree recipients in the United States in 2015 with college debt of $\$ 90,001$ or more was substantially higher for Black Americans: 34.38\%; followed by American Indians or Alaska Natives, 23.5\%; Hispanics, $15.8 \%$; those who are more than one race, $13.9 \%$; Whites, $10.8 \%$; and Asians, 4.7 percent. The rates were $11.3 \%$ for women in general, and $7.3 \%$ of men with $\$ 90,001$ or more in debt (Table 4 ). This high debt burden negatively affects Black American women more because as illustrated above, a majority of them earned all of the doctoral degrees awarded to their race in 2015.

Table 4. Education related debt of doctoral degree recipients in the United States, by sex, citizenship status, ethnicity, and race: 2015.

\begin{tabular}{|c|c|c|}
\hline Mean Cumulative (Undergraduate \& Graduate) Debt & Number & Amount \\
\hline Male & 26,668 & $\$ 20,328$ \\
\hline Female & 22,687 & $\$ 26,556$ \\
\hline U.S. Citizen or Permanent Citizen & 33,701 & $\$ 29,988$ \\
\hline Temporary Visa Holder & 15,379 & $\$ 8,258$ \\
\hline American Indian or Alaskan Native & 119 & $\$ 50,210$ \\
\hline Asian & 3012 & $\$ 15,186$ \\
\hline Black & 2177 & $\$ 62,848$ \\
\hline Hispanic & 2329 & $\$ 36,870$ \\
\hline White & 24,752 & $\$ 28,086$ \\
\hline More than One Race & 899 & $\$ 32,430$ \\
\hline$\$ 90,001$ or more Debt & Number & $\%$ \\
\hline Male & 1953 & 7.3 \\
\hline Female & 2555 & 11.3 \\
\hline U.S. Citizen or Permanent Citizen & 4126 & 12.2 \\
\hline Temporary Visa Holder & 351 & 2.3 \\
\hline American Indian or Alaskan Native & 28 & 23.5 \\
\hline Asian & 143 & 4.7 \\
\hline Black & 746 & 34.3 \\
\hline Hispanic & 367 & 15.8 \\
\hline White & 2667 & 10.8 \\
\hline More than One Race & 125 & 13.9 \\
\hline
\end{tabular}

Source: "Table 40. Education-related debt of doctorate recipients, by sex, citizenship status, ethnicity, and race: 2015. (2016). Doctorate Recipients from U.S. Universities: 2015. National Science Foundation. Retrieved on December 29, 2016 from: https://www.nsf.gov/statistics/2017/nsf17306/data/tab40.pdf. 
Watson (2013: pp. 9-10) points to a research study with a sample of over $2 \%$ of students enrolled at 111 accredited medical schools in the United States in the 2010-2011 academic year, comprising 2355 students. The study finds that $77.3 \%$ of Black American students expected to have debt level of no less than $\$ 150,000$ once they are finished; $65 \%$ of White students; $57.2 \%$ of Hispanic students; and $50 \%$ of Asian students. It is useful to note that Watson (2013) did not say what the actual numbers were in terms of how much debt each group of students had after graduation from medical school. However, one can point to two important observations: that Black American students had the highest level of anticipated debt compared with all other groups of students. This also means that because Black American women tend to earn the majority of medical degrees awarded to Blacks (Kaba, 2013: p. 73), they are more likely to go deeper into debt to pay for their education.

\section{Factors Contributing to the High Cost of College Education and High Student Debt for Black American Women}

What are some of the factors that have caused college graduates or college students to take on so much debt to pay for their education in the United States? Why are substantially more Black Americans, especially Black women in debt than their counterparts from other racial/ethnic groups? One important factor is that in recent decades, the federal government, an important funder of college education of citizens and permanent residents, shifted from providing mostly grants or scholarships to providing more loans with interests to students. The colleges and universities have also changed their method of providing aid to students. Avery \& Turner (2012: p. 165) note of this issue resulting in "...increased public commentary on the level of student borrowing". Long \& Riley (2007: p. 40) point out that the many barriers to access and success of minority students from low-income families can be put into three categories, with cost as one of them. In the 2006-2007 academic year, public four-year colleges and universities had average tuition and fees costing \$5836. The average overall charges totaled $\$ 12,796$. Hornak et al. (2010: p. 487) quoted a student as saying "I am a fine arts major and will be close to $\$ 60,000$ in debt, but feel that I have no other choice but higher education."

Kim (2007: p. 64) notes that when one examines the current trends pertaining to the provision of financial aid to college students in the United States, one major such trend is the new dependence on loans instead of grants. For example, in $1970-1971,70 \%$ of all financial aid given to students were grants, and loans made up the remaining 30 percent. However, by the 2003-2004 academic year, grants made up 38\%, while loans accounted for 60 percent. This shift is due to the changes in federal law. In the early 1990s, law makers of the United States Congress added two important amendments to the Higher Education Act that "...increased loan limits and expanded eligibility for loan programs that aimed to meet the continual rise in tuition levels..." (also see Toby, 2010). Davis et al. (2013: p. 226) point out that policymakers and the people they work for have 
become very concerned in recent decades about the rapid increase in the cost of a college education. This shift to more loans and less grants to pay for a college education has also affected students and their families.

Steinberg et al. (2009: pp. 238-239) claim that qualified college students receive loans and grants from the federal government. For example, 10 million college students and their families received $\$ 83$ billion dollars from the federal government in the form of loans and grants in the 2007-2008 academic year. Although the federal government provides a substantial amount of financial support to college students and their families, it has actually been replacing grants with loans going back to the early 1980s. Another interrelated factor also is that minority students, including Black American students, especially Black women tend to attend for-profit colleges and universities, which tend to cost much more and also results in students to take out higher amounts of loans. According to Iloh \& Toldson (2013: pp. 207-208), Black American students, especially Black females, are among the rising numbers of students from various groups deciding to enroll in for-profit higher education institutions, accounting for $23 \%$, and their Black male counterparts accounting for 19 percent. The price of a for-profit college education is substantially higher than the price at community colleges, with a two-year associate degree costing $\$ 35,000$, but $\$ 8300$ at a similar community college (also see Grinstein-Weiss et al., 2016: p. 167).

This leads to students also taking out credit card loans just to pay for college. Archuleta et al. (2013: p. 51) point to research which claims that: “...financial aid is most often not enough to offset students' financial needs. In these cases, students often turn to credit cards to pay the difference..." Lyons (2004: p. 76) finds in her study of financially at-risk college students that, those who are females, Blacks and Hispanics tend to be the ones having problems paying their credit card bills. Black students in particular tend to be significantly more likely to have credit card debt of $\$ 1000$ or more, and not have money to pay the balance on their credit card in full every month. According to research by Grable \& Joo (2006: p. 407) about college students and credit card debt, compared with students from other racial groups, Black American students were more likely to have more credit card debt, and they also claim more financial stress. When one examines the connection between credit card debt, the racial background of students, the way they behave financially, and stress due to finances, it shows "...that African-American students are affected more dramatically by debt than others".

One would expect that since over 9 out of every 10 Black Americans are native-born citizens (Kaba, 2012: p. 137), and that the figure could be higher for Black American women, they could have more opportunities for scholarships and grants. For example, according to Table 5, of 2109 non-Hispanic Black American doctoral degree recipients in 2015, 11.6\% were awarded teaching assistantships; $21.1 \%$ of non-Hispanic Whites; $17.9 \%$ of those who are more than one race; $17.7 \%$ of Hispanics; $18 \%$ of Asians; $22.5 \%$ of temporary visa holders; 
Table 5. Primary source of financial support of doctoral degree recipients in the United States, by sex, citizenship status, ethnicity, and race: 2015 .

\begin{tabular}{lcccccccccc}
\hline \multicolumn{1}{c}{$\begin{array}{c}\text { Primary } \\
\text { source of } \\
\text { support }\end{array}$} & Total & Male & Female $\begin{array}{c}\text { U.S. Citizen } \\
\text { or Permanent } \\
\text { Resident }\end{array}$ & $\begin{array}{c}\text { Temporary } \\
\text { Visa } \\
\text { Holder }\end{array}$ & $\begin{array}{c}\text { American } \\
\text { Indian or } \\
\text { Alaska } \\
\text { Native }\end{array}$ & Asian & $\begin{array}{c}\text { Non-Hispanic Hispanic/ Non-Hispanic More Than } \\
\text { Black } \\
\text { Latino }\end{array}$ & White \\
One Race
\end{tabular}

Source: "Table 35. Doctorate recipients' primary source of financial support, by broad field of study, sex, citizenship, race, and ethnicity: 2015. (Percent)," (2016). Doctorate Recipients from U.S. Universities: 2015. National Science Foundation. Retrieved December 29, 2016 from: https://www.nsf.gov/statistics/2017/nsf17306/data/tab35.pdf.

16.9\% of American Indians and Alaska Natives; and 19.8\% of U.S. citizens and permanent residents. It was $20.8 \%$ for men and $20.6 \%$ for women in general.

For research assistantships or traineeships, only $13.7 \%$ of non-Hispanic Black Americans were awarded; 7.6\% of American Indians or Alaska Natives; $31.6 \%$ of Asians; $25.1 \%$ of Whites; $22.3 \%$ of those who are more than one race; $17.3 \%$ of Hispanics; $49.3 \%$ of temporary visa holders; and $24.2 \%$ of U.S. citizens and permanent residents. It was $37.1 \%$ for men and $26.2 \%$ for women. For fellowships or grants, it was $28.8 \%$ of non-Hispanic Black Americans who were awarded; $38.4 \%$ of Hispanics; $31.4 \%$ of those who are more than one race; $30.8 \%$ of American Indians or Alaska Natives; 36\% of Asians; and 29\% of non-Hispanic Whites. It was $26.1 \%$ for men and $28.7 \%$ for women in general.

However, when it comes to using their own resources to pay for their education, higher proportion of non-Hispanic Black Americans did so: $41.1 \% ; 39 \%$ of American Indians or Alaska Natives; $20.1 \%$ of Hispanics; $22.4 \%$ of non-Hispanic Whites; $18.8 \%$ of those who are more than one race; $11 \%$ of Asians; $20.9 \%$ of U.S. citizens and permanent residents; and $3 \%$ of temporary visa holders. Again it is because of Black women that the rate is so high for Blacks. This can be observed with women in general (20.2\%) compared to men in general (11.1\%), with Black American women responsible to move the numbers higher for women in general (Table 5).

The scholarship and grant data above tend to indicate that Black Americans have the characteristics of non-citizens, while temporary visa holders tend to have the characteristics of U.S. citizens because they are awarded substantially 
more teaching assistantships, and research assistantships or traineeships than Black Americans, the majority of whom are women (Kaba, 2017).

Examining this issue from parents' education, which can serve as a proxy for class or income, Black American college students or graduates tend to have parents with lower rates of education. In the United States in particular, the higher one's education, the more likely the higher their salary or income. Black Americans have the highest rate of poverty, which was $26.3 \%$ in 2011; the national average was 14 percent (Edwards, 2014: p. 19). According to Easton-Brooks \& Davis (2007: p. 531): "The socioeconomic experiences of African Americans reflect a history of poverty imposed by racism." Also, research shows that Americans from lower classes are less likely to experience upward mobility (Chetty et al., 2014).

According to Easton-Brooks \& Davis (2007: p. 531), the wealth that Black Americans are able to accumulate comes from their current incomes, loans or credit. For European Americans, on the other hand, wealth is inherited from an older generation to a younger one. European American grandparents and parents also tend to provide financial support to younger family members, such as paying for college or buying a home. Black Americans, on the other hand, who receive very little or no capital support, borrow to pay for college and also go into debt to purchase their first home because they are likely to be first-generation home buyers. Compared with their European American counterparts, in paying for their own college education, Black Americans take out a lot more student loans. Grable \& Joo (2006: p. 402) also make a similar claim that due to the fact that the wealth accumulated by Black Americans is so small, there is not much to transfer from an older generation to a younger one. This is not the case for White Americans, however. As a result, this small transfer of wealth within Black American families "...might retard the process of narrowing the racial gap in wealth and living standards" (also see Kaba, 2011: pp. 138-143).

According to Table 6, among the 2015 doctoral degree recipients in the United States, $42.5 \%$ and $37.3 \%$ of the fathers and mothers respectively of Black Americans had a high school diploma or less; $19.1 \%$ and $20.4 \%$ respectively of Whites; $22.6 \%$ and $22.8 \%$ respectively of those who are more than one race; $21.6 \%$ and $30.9 \%$ respectively of Asians; $42.6 \%$ and $39.5 \%$ respectively of American Indians or Alaska Natives; and $36.1 \%$ and $38.1 \%$ respectively of Hispanics. For bachelor's degrees, $16.1 \%$ and $18.8 \%$ of the fathers and mothers respectively of Black doctoral degree recipients in 2015 had earned one; $26.2 \%$ and $29.7 \%$ respectively of Whites; $23.5 \%$ and $31.3 \%$ respectively of Asians; $18.5 \%$ and $28.7 \%$ respectively of those who are more than one race; $14.8 \%$ and $19.3 \%$ respectively of American Indians or Alaska Natives; and $21.7 \%$ and $22.6 \%$ of Hispanics. For advanced degrees, $21.1 \%$ and $21.9 \%$ of the fathers and mothers respectively of Black doctoral degree recipients in 2015 had earned one; $43.6 \%$ and $30.3 \%$ respectively of those who are more than one race; $41.3 \%$ and $31.9 \%$ respectively of Whites; $45.3 \%$ and $26.2 \%$ respectively of Asians; $26.8 \%$ and $22.3 \%$ respectively of Hispanics; and $28.5 \%$ and 19.3\% respectively of American Indians or Alaska Natives (Table 6). 
Table 6. Educational attainment of the parents of doctoral degree recipients in the United States, by sex, citizenship status, ethnicity, and race: 2015 .

\begin{tabular}{|c|c|c|c|c|c|c|}
\hline & Total & & $\begin{array}{l}\text { High } \\
\text { School }\end{array}$ & Some & Bachelor's & Advanced \\
\hline Demographic characteristic & Number & All & or less & College (a) & Degree & Degree \\
\hline \multicolumn{7}{|l|}{ All doctorate recipients } \\
\hline Father's education (b) & 47,326 & 100 & 24.4 & 12.8 & 27.2 & 35.2 \\
\hline Mother's education (c) & 47,540 & 100 & 30.0 & 15.8 & 28.6 & 25.6 \\
\hline \multicolumn{7}{|l|}{ Sex } \\
\hline \multicolumn{7}{|l|}{ Male } \\
\hline Father's education & 25,505 & 100 & 25.3 & 11.9 & 27.8 & 34.9 \\
\hline Mother's education & 25,544 & 100 & 31.8 & 14.8 & 28.9 & 24.5 \\
\hline \multicolumn{7}{|l|}{ Female } \\
\hline Father's education & 21,821 & 100 & 23.4 & 13.9 & 26.7 & 36.1 \\
\hline Mother's education & 21,996 & 100 & 28.0 & 16.9 & 28.3 & 26.8 \\
\hline \multicolumn{7}{|l|}{ Citizenship } \\
\hline \multicolumn{7}{|l|}{$\begin{array}{l}\text { U.S. Citizen or Permanent } \\
\text { Citizen }\end{array}$} \\
\hline Father's education & 32,551 & 100 & 22.1 & 13.7 & 24.8 & 39.4 \\
\hline Mother's education & 32,797 & 100 & 23.8 & 17.7 & 28.6 & 30.0 \\
\hline \multicolumn{7}{|l|}{ Temporary Visa Holder } \\
\hline Father's education & 14,738 & 100 & 30.6 & 10.9 & 32.5 & 25.9 \\
\hline Mother's education & 14,708 & 100 & 43.9 & 11.5 & 28.8 & 15.8 \\
\hline \multicolumn{7}{|l|}{ Race \& ethnicity (U.S. citizen } \\
\hline \multicolumn{7}{|l|}{$\begin{array}{l}\text { American Indian or Alaskan } \\
\text { Native }\end{array}$} \\
\hline Father's education & 115 & 100 & 42.6 & 19.1 & 14.8 & 28.5 \\
\hline Mother's education & 119 & 100 & 39.5 & 21.8 & 19.3 & 19.3 \\
\hline \multicolumn{7}{|l|}{ Asian } \\
\hline Father's education & 2916 & 100 & 21.6 & 9.6 & 23.5 & 45.3 \\
\hline Mother's education & 2922 & 100 & 30.9 & 11.6 & 31.3 & 26.2 \\
\hline \multicolumn{7}{|l|}{ Black } \\
\hline Father's education & 1983 & 100 & 42.5 & 20.4 & 16.1 & 21.1 \\
\hline Mother's education & 2056 & 100 & 37.3 & 22.0 & 18.8 & 21.9 \\
\hline \multicolumn{7}{|l|}{ Hispanic } \\
\hline Father's education & 2235 & 100 & 36.1 & 15.4 & 21.7 & 26.8 \\
\hline Mother's education & 2273 & 100 & 38.1 & 17.0 & 22.6 & 22.3 \\
\hline \multicolumn{7}{|l|}{ White } \\
\hline Father's education & 24,130 & 100 & 19.1 & 13.4 & 26.2 & 41.3 \\
\hline Mother's education & 23,239 & 100 & 20.4 & 18.1 & 29.7 & 31.9 \\
\hline \multicolumn{7}{|l|}{ More than one race } \\
\hline Father's education & 866 & 100 & 22.6 & 15.2 & 18.5 & 43.6 \\
\hline Mother's education & 874 & 100 & 22.8 & 18.2 & 28.7 & 30.3 \\
\hline \multicolumn{7}{|c|}{$\begin{array}{l}\text { ancludes those who attended college but did not earn a bachelor's; 'Total count excludes } 7129 \text { who did not } \\
\text { report father's education and } 551 \text { (1.0\%) who reported "not applicable/unknown"; 'Total count excludes } \\
7096 \text { who did not report mother's education and } 368 \text { (0.7\%) who reported "not applicable/unknown". } \\
\text { Source: "Table 33. Educational attainment of doctorate recipients' parents, by sex, citizenship, race, ethnic- } \\
\text { ity, and broad field of study: 2015," (2016). Doctorate Recipients from U.S. Universities: 2015. National } \\
\text { Science Foundation. Retrieved on January 2, } 2016 \text { from: } \\
\text { https://www.nsf.gov/statistics/2017/nsf17306/data/tab33.pdf. }\end{array}$} \\
\hline
\end{tabular}


Furthermore, not only has the system shifted from scholarships or grants to loans, but increasingly the remaining grants or scholarships tend to go to students from middle-class families or those families with higher incomes, instead of low-income families, including Black Americans, who are the poorest racial group in the country. Also, there is a gradual trend of awarding more merit-based aid than need-based aid. Kim's (2007: p. 80) research findings show that students who earn their bachelor's degree by the 2000-2001 academic year tend to be of normal college age, dependent, and had at least one parent with a bachelor's degree. When these students are compared to students who had not earned their degree in that 2000-2001 academic year in the study, they normally come from families with higher incomes, enrolled in college immediately after graduation from high school, were not employed while in college, and they also graduated from highly selective colleges and universities.

Trent et al. (2006: pp. 1740-1741) point to the ways in which students who graduated in 1992-1993 experience their student debt burden is similar to the experience of inequality based on race, ethnicity and class in the history of the United States. This means that students from wealthy or well-off families tend to have little to no debt, while those from poorer families (especially Black American and Hispanic families, than White families) have substantial debt burden. "That is to say, low- and lower-middle-income students, Black and Hispanic students who successfully attain a college degree are paying more for postsecondary education." The reason is that the law requires that students with loans pay interest on those loans for 10 years "...borrowers pay a 33\% premium on the portion of college paid for by student loans. Thus, they receive a lower return on their investment in higher education..."

According to Malcolm \& Dowd (2012: pp. 292-293), Asian students who earn their bachelor's degree in STEM fields borrowed less for college and have little to no debt primarily because their families paid for their education, while Black Americans took out a lot more in loans and received little or no support from their families for their education. The authors conclude that their “...African American counterparts employ distinct college financing strategies, which appear to be rooted in well-documented differences in accumulated family wealth".

In addition, the Pell Grant, which Black American students are more likely to seek have strict requirements that make it difficult for students with criminal records, making them ineligible and tends to affect Black American students more. For example, the study by Brame et al. (2014: p. 471) claims that by age $23,49 \%$ of Black American males and $38 \%$ of White American males have been arrested. Hornak et al. (2010: p. 487) note that $37 \%$ of students in their research study received Pell Grants, 67\% received federal loans, and 30\% received private loans. For those students who received federal loans, $43 \%$ received over $\$ 3000$ and $17 \%$ received over $\$ 6000$. Steinberg et al. (2009: pp. 238-239) note that federal grant aid is being shifted to merit-based assistance 
instead of need-based assistance. The same shift is happening with state grant aid to college students. Pell Grant remains the only aid designed for students from low-income families, including those from families with incomes under $\$ 40,000$. In the $2005-2006$ academic year, $86 \%$ of undergraduate students who received a Pell Grant were from families earning less than $\$ 40,000$. Over one out of every four undergraduate students (5.2 million students) received a Pell Grant in the 2006-2007 academic year, accounting for $\$ 12.9$ billion. The average Pell Grant amount was $\$ 2,494$.

Rubin (2011: p. 676) points out that the Pell Grant has a number of implications to students for a number of reasons. It represents a foundation stage of assistance because students who are eligible for it tend to also be eligible for a number of other federal and non-federal assistance programs, such as the $\mathrm{Na}$ tional Science and Mathematics Access to Retain Talent (SMART) Grant, and the Academic Competitiveness Grant. Colleges and universities also tend to focus their need-based assistance to students qualified for Pell Grant. Of the \$116 billion set aside to be spent on different "financial aid initiatives" by the U.S. Department of Education in fiscal-year 2009-2010, Pell Grant accounted for \$21.8 billion (18.8\%). No other financial aid program was allocated such an amount. Trent et al. (2006: p. 1743) note that studies examining the types of financial aid awarded to students show that minority students tend to have a lot more debt burden. The type of aid to students also determines whether they attend their first choice of institutions. Also "...students who borrow and fail to complete are more likely to be lower income, first-generation college students".

Steinberg et al. (2009: pp. 238-239) point out that when it comes to offering merit-based grants to students, those from wealthy or high-income families tend to benefit. While need-based and non-need-based grants have increased over the years, more gains have been made in non-need-based grants, with students from high-income families benefiting. A negative relationship is observed between the proportion of students from low-income or poor families and college access to National Merit Scholarships, with “.... drop of four Pell Grant recipients for every 10 additional institutionally funded National Merit Scholarship enrollees".

Explaining the ongoing shift of government college aid policy to middle-class families, Long \& Riley (2007: p. 45) point out that it resumed in 1997 when tax credits were created by the federal government. To benefit, families must pay taxes, benefiting those with incomes of $\$ 50,000$ or more. Families with incomes less than $\$ 30,000$ are less likely to qualify. College savings plans also benefit high-income families, with $90 \%$ of such plans having at least one member with a higher education degree. The median income among this group is $\$ 100,000$, with a high proportion of families, including minority families without such a median income. The authors add that "...the shift of financial aid policy toward merit based programs and tax credits have been especially detrimental to students at the bottom of the income distribution". 


\section{Recommendations for Managing the Heavy Debt Burden on Black American Students}

There must be ways to reduce this high student debt burden negatively affecting Black Americans, especially Black women. They have made extraordinary efforts in the past four decades to get to this point and it would be a disappointing setback for the country if these educational gains are reversed. According to Thomas et al. (2009: p. 159): "To continue this positive, upward trend among African Americans, particularly African American women, researchers must use empirical findings to identify factors that contribute to persistence toward academic attainment in higher education." Among some of the factors that have contributed to this perseverance especially for Black American women, are religiosity, discipline, diligence, they commit less crimes, they avoid drugs and alcohol, and emphasis by mothers of Black American females to focus on their education instead of getting married (Dill, 1983: p. 140; Kaba, 2008: pp. 327-328).

One suggestion or recommendation to help solve the problem of the high cost of higher education to Black Americans, especially Black women in doctoral programs or in graduate school is to have certain percentages of grants or scholarships to be reserved for them. This is because the exclusion of Black Americans from these scholarships or grants results in fewer of them actually having the opportunity to enroll in doctoral degree programs or in graduate school. As Morehouse \& Dawkins (2006: p. 563) note: "The underrepresentation of African Americans among doctoral degree recipients in the U.S. is a long-standing pattern." As noted above, Black American women accounted for only 3\% of doctoral degrees awarded in 2015, even though they account for $7.4 \%$ of the total population of the United States; and Black American men accounted for $2.4 \%$ and they accounted for $6 \%$ of the total population.

Davis et al. (2013: p. 226) note that as a racial or ethnic group most likely to come from low income families and are affected the most by the high cost of higher education, grant aid plays an important role in expanding their access to a college education. Therefore to understand "...how the timing, packaging, marketing, and actual distribution of grant aid affects different types of students is fundamentally important to expand college access and choice for all groups of students". Grant providers from federal, state, to higher education institutions could work in a coordinated manner and begin to identify students from various socioeconomic backgrounds from high school and create programs that would make the process of enrolling them in college less financially difficult. These programs should be tailor-made for each income bracket of students entering into college. For example, discussing ways to increase the number of Black American students in doctoral programs, Morehouse \& Dawkins (2006: p. 563) point out that efforts that have been made to solve this issue centered on three points. The first is that the number of well-prepared Black American students already admitted to college should be increased. The second point is for the provision of specific financial grant aid that targets Black American students. The third point is that Black American students already admitted into doctoral pro- 
grams should be awarded grants that will help them face the challenges that come with doing doctoral work.

Malcolm \& Dowd (2012: pp. 292-293) claim in their study that: "For all racial groups and Latinos in our study, borrowing reduces the chances of attending graduate school." Discussing the impact of debt on students and graduate school attendance, Trent et al. (2006: p. 1743) note that: “...accumulated loan debt matters for decisions about attending graduate school, such that those with greater debt opt out." Trent et al. (2006: pp. 1743-1744) cite a scholar who claims that loan debt from undergraduate education tends to limit the ability of students to transition into graduate school the year after earning their bachelor's degree. For example, students who graduate with a bachelor's degree with college debt of $\$ 5000$ or higher tend to be less likely to enroll in graduate or professional school than their counterparts without college debt.

According to findings from the study conducted by Kim (2007: p. 90), due to college debt burden, low-income students had difficulty completing their college education. This was especially the case for Black American students. "An additional \$1000 in loans had a significant negative effect for Black students, as compared to a slight positive effect for White students." Watson (2013: pp. 9-10) tells a story of a Black American student who had graduated from college with a debt of $\$ 40,000$ but decided not to pursue a dream of attending medical school because of fear of going deeper into debt: "I have so many loans from my undergraduate years, and the cost of medical school is simply too much...I'm not trying to be in debt for the rest of my life...." The student adds that he had a lot of bills to take care of: “....and I can't think about the possibility of taking on additional financial debt at this time, so I think I've come to terms with my situation... It's unfortunate, but that's just the way it is." Therefore, one of the key policies would seem to be lowering the cost of undergraduate instruction.

Writing about the challenges that Black American women face in graduate school, Jones et al. (2013: p. 327) point out that, these students have to deal with the barriers of race and gender, which can impact their success in academia. "Racism, sexism, and other interlocking oppressions create an 'outsider-within' status for Black women in many PWIs [Predominantly White Institutions]." Despite their educational achievement, they must deal with the negative images of their group in society which "...deem all Black women-regardless of their education, status, or position-as inferior, subservient, hostile, domineering, hypersexual or overly masculine". Thomas et al. (2009: pp. 159-160) write that Black American women face what they termed as "concrete ceiling" within American higher education. While women in general face institutional barriers due to their sex, Black American women suffer even more due to their race. There are usually certain levels within the system that they cannot break into due to their sex and race. "It is the combination of these factors that is unique to African American women, which results in the cumulative or pooled outcome of these barriers identified as the 'concrete ceiling' effect". According to Jones et al. 
(2013: p. 328), “The growth and presence of Black women in the professoriate is inexorably linked to the access, entry, and retention of Black women in doctoral programs" (also see Davis \& Maldonado, 2015: p. 328). If Black American women do not have substantial numbers in doctoral programs, it makes it difficult for them to have adequate representation in the professoriate. This also affects the diversity of the professoriate and its sustained success because the perspectives of a very important group in the society are missing.

The United States federal government provides billions of dollars in grants to doctoral programs or graduate schools across the country. State governments also provide grants to these programs. However, both these entities have shifted their method of funding from grans to loans. As a result, well-prepared students from low-income families are experiencing difficult challenges in accessing higher education. According to Trent et al. (2006: pp. 1740-1741), “The shift in financial aid policy that has occurred at the federal, state, and institutional levels has created a shortage of aid-need-based grant aid, in particular". In addition, as tuition and fees increase, this government shift in funding students' college education has created a situation in which "...fully prepared college graduates from low- and moderate-income families face significant financial barriers to enrolling in and remaining in college".

Two important programs that have been established in recent decades to help low-income students earn college education are the Gates Millennium Scholars (GMS) Program and the McKnight Doctoral Fellowship Program. These two programs have contributed significantly to helping low-income students earn college degrees, from bachelor's degrees to doctoral degrees. Davis et al. (2013: p. 227) point out that the Gates Millennium Scholars (GMS) Program, which is primarily run by the United Negro College Fund (UNCF), was established in 1999 with \$1.6 billion in grant money for two decades to help low-income students pay for their college education. One important component of this program is its nation-wide scholarship initiative. This initiative provides grant assistance "...that covers the full cost of attendance for 1000 high-achieving, low-income students of color each year to enroll in their college of choice and earn their undergraduate and graduate degrees". The study of Morehouse \& Dawkins (2006: p. 567) examines the outcomes of the McKnight Doctoral Fellowship Program, which started awarding fellowships to Black Americans in 1984. The authors claim that the program has awarded 559 scholarships from 1984 to 2006. Of that total, 226 (40.4\%) have earned their doctoral degrees. Another 262 (46.9\%) were getting their doctoral degrees. Since the program started, only 71 (12.7\%) students have not been successful in getting their doctoral degrees. Women accounted for $58.1 \%$ of the scholarships awarded. "McKnight fellows take an average of 5.5 years to complete their doctorate compared to the national average of 7.5 years."

Higher education institutions in the United States also provide a significant number of scholarships to students. According to Steinberg et al. (2009: pp. 238-239), higher education institutions in the United States have been spending 
their mostly limited funds or resources to help: “...lower-income students in meeting the costs of attendance and to seek the highest quality students possible." O'Connor (2002: p. 857) points out that: “Comparatively, the notion of opportunity signifies the availability of specific institutional, material, or human resources that might be employed in the negotiation of structured constraints." O'Connor (2002) adds that opportunity can then be certified using institutionalized and non institutionalized resources. These institutionalized resources tend to "...reflect systematic and structured supports that counteract or circumscribe educational constraint (e.g., college admissions procedures that are informed by policies of affirmative action)".

Morehouse \& Dawkins (2006: pp. 564-565) present three categories to explain the factors that influence enrollment in graduate school and progress of students in doctoral programs. The categories are: institutional, environmental, and motivational. Institutional factors can be policies connected to admission requirements of colleges and universities, financial assistance, research assistantships, and any other types of support that will help students successfully complete a doctoral program. Environmental factors can be the climate on campus, the availability of mentors and role models "... who can serve as part of a system of academic and social support". Finally, the motivational factors can be the attitudes, beliefs and values of students useful in keeping “...the level of intrinsic and extrinsic achievement impetus necessary for sustaining them through the rigors of doctoral study".

\section{Conclusion}

This article began by providing examples showing that Black American females tend to work a lot harder for the same or similar opportunities earned by their male counterparts, and members of other groups. The examples presented are fewer of them than their male counterparts are elected to the U.S. Congress; fewer of them than Black men and Whites are college presidents; and they earn less income than their male counterparts, and others in the top job category in the country. The article presented data showing that Black Americans, especially Black women, have made substantial progress in college enrollment and college degree attainment, even though there is a visible gap between them and other racial groups in the country such as Asians and Whites. This success has been due primarily to student loans, which have contributed to a significant number of Black Americans to attain college education.

The article pointed out, however, that Black Americans, especially Black women pay a lot more for their college education than other racial groups, and temporary residents. One major factor for this relative high cost of college education to Black Americans is the shift from mostly grants to loans that the federal and state governments provide to students, with Blacks experiencing the largest amount of debt burden. Due to competition, colleges and universities tend to provide substantial numbers of scholarships such as teaching and research assis- 
tantships to temporary resident students, and this reduces the opportunities for citizens, especially Black American women. Private scholarships and grants such as the Gates Millennium Scholars (GMS) and the McKnight Doctoral Fellowship Program have helped to ease the debt burden for some Black American students by funding their college education. Higher education institutions have also used some of their limited resources to provide financial assistance to minority students, including Black Americans. However, the total number of Black American students is so large and such a very high proportion of Black Americans are in poverty that these private grants and scholarships from foundations, and assistance from higher education institutions are not sufficient to reduce their overall debt burden. As a result, they are taking out substantial amounts of student loans.

\section{References}

Archuleta, K. L., Dale, A., \& Spann, S. M. (2013). College Students and Financial Distress: Exploring Debt, Financial Satisfaction, and Financial Anxiety. Journal of Financial Counseling and Planning, 24, 50-62.

Avery, C., \& Turner, S. (2012). Student Loans: Do College Students Borrow Too Much Or Not Enough? Journal of Economic Perspectives, 26, 165-192.

https://doi.org/10.1257/jep.26.1.165

Brame, R., Bushway, S. D., Paternoster, R., \& Turner, M. G. (2014). Demographic Patterns of Cumulative Arrest Prevalence by Ages 18 and 23. Crime \& Delinquency, 60, 471-486. https://doi.org/10.1177/0011128713514801

Brown, N. E., \& Banks, H. (2014). Black Women's Agenda Setting in the Maryland State Legislature. Journal of African American Studies, 18, 164-180. https://doi.org/10.1007/s12111-013-9260-7

Chetty, R., Hendren, N., Kline, P., \& Saez, E. (2014). Where Is the Land of Opportunity? The Geography of Intergenerational Mobility in the United States (pp. 1-61). National Bureau of Economic Research (NBER). NBER Working Paper Series. http://obs.rc.fas.harvard.edu/chetty/mobility_geo.pdf

Cumulative Debt of Bachelor's Degree Recipients by Sector over Time (2015). Trends in Higher Education. The College Board.

http://trends.collegeboard.org/student-aid/figures-tables/cumulative-debt-bachelors-re cipients-sector-time

Davis, D., \& Maldonado, C. (2015). Shattering the Glass Ceiling: The Leadership Development of African American Women in Higher Education. Advancing Women in Leadership, 35, 48-64.

Davis, R. J., Nagle, B., Richards, D. A. R., \& Awokoya, J. T. (2013). The Impact of the Gates Millennium Scholars Program on College Choice for High-Achieving, Low-Income African American Students. Journal of Negro Education, 82, 226-357. https://doi.org/10.7709/jnegroeducation.82.3.0226

Dill, B. T. (1983). Race, Class, and Gender: Prospects for an All-Inclusive Sisterhood. Feminist Studies, 9, 131-150. https://doi.org/10.2307/3177687

Dittmar, K. (2015). Voices. Votes. Leadership. The Status of Black Women in American Politics. Center for American Women in Politics.

http://www.cawp.rutgers.edu/sites/default/files/resources/hh2015.pdf 
Easton-Brooks, D., \& Davis, A. (2007). Wealth, Traditional Socioeconomic Indicators, and the Achievement Debt. The Journal of Negro Education, 76, 530-541.

Edwards, A. N. (2014). Dynamics of Economic Well-Being: Poverty, 2009-2011. United States Census Bureau. http://www.census.gov/prod/2014pubs/p70-137.pdf

Fact Sheets by Region: 2015 (2016). Open Doors. Institute of International Education. http://www.iie.org/Research-and-Publications/Open-Doors/Data/Fact-Sheets-by-Regio n/2015\#.V4uCo6_2Y2w

Franklin, J. H., \& Moss, A. A. (1994). From Slavery to Freedom: A History of African Americans (7th ed.). New York, NY: McGraw-Hill.

Grable, J. E., \& Joo, S. H. (2006). Student Racial Differences in Credit Card Debt and Financial Behaviors and Stress. College Student Journal, 40, 400-408.

Grinstein-Weiss, M., Perantie, D., Taylor, S. H., Guo, S., \& Raghavan, R. (2016). Racial Disparities in Education Debt Burden among Low-Income Households. Children and Youth Review, 65, 166-174.

Hornak, A. M., Farrell, P. L., \& Jackson, N. J. (2010). Making It (or Not) on a Dime in College: Implications for Practice. Journal of College Student Development, 51, 481-495. https://doi.org/10.1353/csd.2010.0003

Iloh, C., \& Toldson, I. A. (2013). Black Students in $21^{\text {st }}$ Century Higher Education: A Closer Look at For-Profit and Community Colleges. Journal of Negro Education, 82, 205-212. https://doi.org/10.7709/jnegroeducation.82.3.0205

Jones, T. B., Wilder, J. A., \& Osborne-Lampkin, L. T. (2013). Employing a Black Feminist Approach to Doctoral Advising: Preparing Black Women for the Professoriate. Journal of Negro Education, 82, 326-338, 356-358.

Kaba, A. J. (2017). Educational Attainment, Citizenship, and Black American Women in Elected and Appointed National Leadership Positions. The Review of Black Political Economy, 44, 99-136.

Kaba, A. J. (2016). Conceptualizing Tolerance as Recognition: Black American Endowed and Distinguished Professors of Education in US Colleges and Universities. Sociology Mind, 6, 1-31. https://doi.org/10.4236/sm.2016.61001

Kaba, A. J. (2016). A Statistical Report on the Educational Attainment Status of Black Americans. African Renaissance, 11, 79-100.

Kaba, A. J. (2013). Black Americans, Gains in Science and Engineering Degrees, and Gender. Sociology Mind, 3, 67-82. https://doi.org/10.4236/sm.2013.31012

Kaba, A. J. (2012). The Exclusion of Black Women from National Leadership Positions in the United States: Taxation with Limited Representation. Sociology Mind, 2, 133-140. https://doi.org/10.4236/sm.2012.22017

Kaba, A. J. (2011). Explaining the Causes of the Black-White Wealth Gap in the United States. Sociology Mind, 1, 138-143. https://doi.org/10.4236/sm.2011.13017

Kaba, A. J., \& Ward, D. E. (2009). African Americans and U.S. Politics: The Gradual Progress of Black Women in Political Representation. Review of Black Political Economy, 36, 29-50.

Kaba, A. J. (2008). Race, Gender and Progress: Are Black American Women the New Model Minority? Journal of African American Studies, 12, 309-335.

Kaba, A. J. (2005). Progress of African Americans in Higher Education Attainment: The Widening Gender Gap and Its Current and Future Implications. Education Policy Analysis Archives, 13, 12-13.

Kim, D. (2007). The Effect of Loans on Students' Degree Attainment: Differences by Student and Institutional Characteristics. Harvard Education Review, 77, 64-100, 127. 
https://doi.org/10.17763/haer.77.1.n14t6910q8292784

Long, B. T., \& Riley, E. (2007). Financial Aid: A Broken Bridge to College. Harvard Educational Review, 77, 39-63. https://doi.org/10.17763/haer.77.1.765h8777686r7357

Lyons, A. C. (2004). A Profile of Financially At-Risk College Students. The Journal of Consumer Affairs, 38, 56-80.

Malcolm, L. E., \& Dowd, A. C. (2012). The Impact of Undergraduate Debt on the Graduate School Enrollment of STEM Baccalaureates. Review of Higher Education, 35, 265-305. https://doi.org/10.1353/rhe.2012.0007

McGirt, E. (2016). Why Race and Culture Matter in the C-Suite. Fortune Magazine. http://fortune.com/black-executives-men-c-suite/

Morehouse, L., \& Dawkins, M. P. (2006). The McKnight Doctoral Fellowship Program: Toward a Seamless Approach to the Production of African American Doctorates. Journal of Negro Education, 75, 563-571.

Musser, J. (1997). African American Women and Education: Marita Bonner's Response to the "Talented Tenth". Studies in Short Fiction, 34, 73-85.

O'Connor, C. (2002). Black Women Beating the Odds from One Generation to the Next: How the Changing Dynamics of Constraint and Opportunity Affect the Process of Educational Resilience. American Educational Research Journal, 39, 855-903. https://doi.org/10.3102/00028312039004855

Rubin, R. B. (2011). The Pell and the Poor: A Regression Discontinuity Analysis of on Time College Enrollment. Research in Higher Education, 52, 675-692. https://doi.org/10.1007/s11162-011-9215-6

Steinberg, M. P., Piraino, P., \&Haveman, R. (2009). Access to Higher Education: Exploring the Variation in Pell Grant Prevalence among U.S. Colleges and Universities. The Review of Higher Education, 32, 235-270.

Table 230. Educational Attainment, by Race, Hispanic Origin, and Sex, 1970-2010 (2012). Statistical Abstract of the United States. United States Census Bureau. http://www2.census.gov/library/publications/2011/compendia/statab/131ed/tables/edu c.pdf

Thomas, D. M., Love, K. M., Roan-Belle, C., Tyler, K. M., Brown, C. L., \& Garriott, P. O. (2009). Self-Efficacy, Motivation, and Academic Adjustment among African American Women Attending Institutions of Higher Education. Journal of Negro Education, 78, 159-171.

Thomas, V. G., \& Jackson, J. A. (2007). The Education of African American Girls and Women: Past to Present. Journal of Negro Education, 76, 357-372.

Toby, J. (2010). How Scholarship Morphed into Financial Aid. Academic Questions, 23, 298-310. https://doi.org/10.1007/s12129-010-9174-y

Trent, W. T., Lee, H. S., \& Owens-Nicholson, D. (2006). Perceptions of Financial Aid among Students of Color: Examining the Role(s) of Self-Concept, Locus of Control, and Expectations. American Behavioral Scientist, 49, 1739-1759.

https://doi.org/10.1177/0002764206289146

United States Bureau of Labor Statistics (2016). Earnings and Employment by Occupation, Race, Ethnicity, and Sex, 2010. http://www.bls.gov/opub/ted/2011/ted_20110914.htm

United States Census Bureau (2013). School Enrollment: CPS October 2012 Detailed Tables. http://www.census.gov/hhes/school/data/cps/2012/tables.html

United States Census Bureau (2016). School Enrollment: CPS October 2015 Detailed Tables. https://www.census.gov/hhes/school/data/cps/2015/tables.html 
U.S. Census Bureau (2017). Educational Attainment in the United States: 2016 Detailed Tables. Retrieved on August 2, 2017 from:

https://www.census.gov/data/tables/2016/demo/education-attainment/cps-detailed-tab les.html

Watson, J. (2013). Drowning in Debt. Diverse: Issues in Higher Education, 30, 9-10.

Williams, L. F. (2001). The Civil Rights Black Power Legacy: Black Women Elected Officials at the Local, State, and National Levels. In B. Collier-Thomas, \& V. P. Franklin (Eds.), Chapter in Sisters in the Struggle (pp. 306-331). New York, NY: NYU Press. 